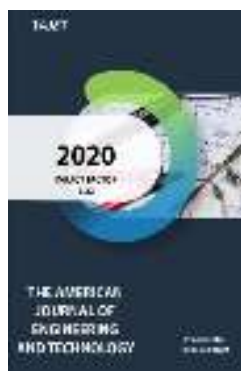

Journal Website: http://usajournalshub.c om/index,php/tajet

Copyright: Original content from this work may be used under the terms of the creative commons attributes 4.0 licence.

\section{Catalytic Synthesis Of Lower Olefins From Methanol And Dimethyl Ether}

\author{
Sh.Ch.Aslanov \\ Shurtan Gas Chemical Complex LLC, Uzbekistan \\ A.Q.Buxorov \\ Shurtan Gas Chemical Complex LLC, Uzbekistan \\ N. I. Fayzullaev \\ Doctor Of Technical Sciences, Professor, Samarkand State University, Uzbekistan
}

\title{
ABSTRACT
}

Currently, the main source of feedstock for the production of lower olefins is oil. The implementation of the sequential change " $\mathrm{CH}_{4} \rightarrow \mathrm{CH} 3 \mathrm{OH} \rightarrow$ lower olefins" allows us to consider natural gas as an alternative raw material for the production of expensive raw materials for petrochemicals-ethylene and propylene. The most promising catalysts for converting methanol to olefins are crystalline microporous silicoaluminophosphates (SAPO-34 and SAPO-18) With a chabazite structure and high siliceous zeolites (HSZ) synthesized from kaolin. Despite the existence of industrial processes for converting methanol using HSZ to olefins, the improvement of these catalysts is an urgent task in order to increase the selectivity and stability of the operation of ethylene and propylene. Therefore, we conducted the process of producing ethylene and propylene from methanol by incorporating metals of various nature from natural kaolin to HSZ. The purpose of this work is to study the effect of the nature and amount of the introduced metal on the physicochemical and catalytic properties of the HSZ.

\section{KEYWORDS}

Alternative fuel, catalysts, economical use of natural gas, high siliceous zeolites, low-carbon, natural gas.

\section{ABBREVIATION}

HSZ - high siliceous zeolites; MTO - methanol to olefins; DTO - dimethyl ether to olefins; ZSM-5 -

Zeolite Socony Mobil 5; HMDA - Hexamethylenediamine; Dimethyl ether-DME; 


\section{INTRODUCTION}

Rational use of oil and gas will allow the chemical industry to develop at a higher level. Special attention is paid to the use of high-efficiency, low-waste, economical, environmentally friendly technologies for the efficient use of oil and natural gas, as well as environmental protection. At a time when oil reserves are declining, natural gas is of great interest as an alternative fuel in petrochemical production. The current conventional method of converting natural gas into liquid fuel is multistage, at high temperature and high pressure. There are 3 most important ways to recover ethylene from natural gas [1-5]. The first method is the production of ethylene by the synthesis of dimethyl ether or methanol, the second - by dimerization of methane, the third - through methyl chloride.

\section{Extraction of olefins from natural gas with methyl chloride.}

Production of methyl chloride by methane oxychlorination [6-9]:

$$
n \mathrm{CH}_{4}+n \mathrm{HCl}+\frac{n}{2} \mathrm{O}_{2} \stackrel{\mathrm{CuCl}: \mathrm{KCl}_{\mathrm{LaCl}}=1: 1: 0,3}{\longrightarrow} n \mathrm{CH}_{3} \mathrm{Cl}+n \mathrm{H}_{2} \mathrm{O}
$$

The methane oxychlorination reaction proceeds at atmospheric pressure at $550-4200{ }^{\circ} \mathrm{C}$. $\mathrm{CH}_{4}: \mathrm{HCl}: \mathrm{O}_{2}=12: 2: 1$; volumetric velocity $8100 \mathrm{I} / \mathrm{l}$ cat. hour; $\tau=1,8$ sec. $\tau=1,8 \mathrm{~cm}^{3}$.

\section{Conversion of methyl chloride to olefins.}

$$
n \mathrm{CH}_{3} \mathrm{Cl} \rightarrow \mathrm{C}_{2} \mathrm{H}_{4}+\mathrm{C}_{3} \mathrm{H}_{6}+\mathrm{C}_{4} \mathrm{H}_{8}+\mathrm{nHCl}
$$

- Catalyst-SAPO-34

- Methyl chloride conversion $-80 \%$

- Selectivity to ethylene and propylene $80-85 \%$

- Temperature $-420-450^{\circ} \mathrm{C}$

Preparation of ethylene by the synthesis of dimethyl ether or methanol involves the following processes [10-15]:

$$
\begin{aligned}
& 2 \mathrm{CH}_{4}+\mathrm{H}_{2} \mathrm{O}+\mathrm{O}_{2} \rightarrow \mathrm{CO}+\mathrm{CO}_{2}+5 \mathrm{H}_{2} \\
& \mathrm{CO}+\mathrm{CO}_{2}+5 \mathrm{H}_{2} \rightarrow 2 \mathrm{CH}_{3} \mathrm{OH}+\mathrm{H}_{2} \mathrm{O} \\
& n \mathrm{CH}_{3} \mathrm{OH} \rightarrow \mathrm{C}_{2} \mathrm{H}_{4}+\mathrm{C}_{3} \mathrm{H}_{6}+\mathrm{C}_{4} \mathrm{H}_{8}+\mathrm{C}_{n} \mathrm{H}_{2 n}+n \mathrm{H}_{2} \mathrm{O}
\end{aligned}
$$

V.N. Rozanov and Yu. A. Treger in their comments [12-16] considered various technologies for the production of ethylene and propylene from natural gas.

Of all known methods, it is easiest to obtain ethylene by oxycondensation of methane, which is prevented by low ethylene yields.

The natural gas to ethylene methanol conversion chain consists of 3 steps: 
- $\quad$ Synthesis - gas extraction:

$$
\begin{aligned}
& \mathrm{CH}_{4}+\mathrm{H}_{2} \mathrm{O} \leftrightarrow \mathrm{CO}+3 \mathrm{H}_{2}-206 \kappa \varkappa / \mathrm{mol}(1) \\
& \mathrm{CH}_{4}+\mathrm{CO}_{2} \leftrightarrow 2 \mathrm{CO}+2 \mathrm{H}_{2}-247 \kappa \varkappa / \mathrm{mol}(2) \\
& \mathrm{CH}_{4}+1 / 2 \mathrm{O}_{2} \leftrightarrow \mathrm{CO}+2 \mathrm{H}_{2}-36 \kappa \% / \mathrm{mol}(3)
\end{aligned}
$$

- Extraction of methanol:

$$
\mathrm{CO}+\mathrm{CO}_{2}+5 \mathrm{H}_{2} \rightarrow 2 \mathrm{CH}_{3} \mathrm{OH}+\mathrm{H}_{2} \mathrm{O}
$$

$\mathrm{T}=220-280^{\circ} \mathrm{C} ; \mathrm{P}=5-10 \mathrm{MPa}$, catalyst $\mathrm{Cu} / \mathrm{Zn}$.

- Conversion of methanol in the presence of a catalyst:

$$
n \mathrm{CH}_{3} \mathrm{OH} \rightarrow \mathrm{C}_{2} \mathrm{H}_{4}+\mathrm{C}_{3} \mathrm{H}_{6}+\mathrm{C}_{4} \mathrm{H}_{8}+\text { other hydrocarbons }+n \mathrm{H}_{2} \mathrm{O}
$$

The conversion rate of methane in synthesis gas extraction processes (17-23) is high, in reaction (3) oxygen is fully involved in the reaction. Methane homologues are completely transformed into $\mathrm{CO}$ and $\mathrm{H}_{2}$. The reaction mechanism of the MTO process (methanol to olefins-MTO) is fully studied in [24-27]. Catalysts of MTO and DTO processes (dimethyl ether to olefins), their thermodynamics, kinetics and mechanism are described in [28]. Many catalysts have been tested in the MTO reaction [29-32]. Most often, zeolites of the ZSM-5 type and molecular sieves of the SAPO type are tested in MTO reactions. In zeolites HZSM-5 paraffin, aromatics, cycloparaffins and olefins $C_{6+}$ are obtained. More than 30 years have passed since the methane oxycondensation reaction was discovered, but this reaction has not yet been introduced into the industry due to the lack of a stable catalyst with high activity and efficiency [23-36].

\section{Indicators of the methane oxidation process.}

$2 \mathrm{CH}_{4}+1 / 2 \mathrm{O}_{2} \rightarrow \mathrm{C}_{2} \mathrm{H}_{6}+2 \mathrm{H}_{2} \mathrm{O}$

$2 \mathrm{CH}_{4}+\mathrm{O}_{2} \rightarrow \mathrm{C}_{2} \mathrm{H}_{4}+2 \mathrm{H}_{2} \mathrm{O}$

- Hydrocarbon yield C2 up to $25 \%$

- Hydrocarbon selectivity S2 - up to 80\%.

- Selectivity to ethylene - up to $55 \%$.

\section{EXPERIIMENT}

The synthesis of catalysts was carried out from a reaction mixture of the composition $\mathrm{xMeO}$ * $\mathrm{Al}_{2} \mathrm{O}_{3}$ * $2 \mathrm{~B}_{2} \mathrm{O}_{3}$ * $2 \mathrm{SiO}_{2}$ * $4\left(\mathrm{C}_{2} \mathrm{H}_{5}\right)_{4} \mathrm{NOH}$ * $96 \mathrm{H}_{2} \mathrm{O}$, where $x=0,005 \div 0,1 . M e=M g, Z n, Z r$. The HSZ sample was synthesized by the hydrothermal method. As the initial components, a solution of the salt $\mathrm{Al}\left(\mathrm{NO}_{3}\right)_{3} \cdot 9 \mathrm{H}_{2} \mathrm{O}$ and a solution of liquid glass $\mathrm{Na}_{2} \mathrm{SiO}_{3}\left(29 \% \mathrm{SiO}_{2} ; 9 \% \mathrm{Na}_{2} \mathrm{O} ; 62 \%\right.$ $\mathrm{H}_{2} \mathrm{O}$ ) were obtained. Hexamethylenediamine (GMDA) was obtained as a matrix. The reaction mixture was prepared by vigorously stirring aqueous solutions of the components at $\mathrm{pH} \cong$ 10.8 and adding a solution of $\mathrm{HNO}_{3}(0,1 \mathrm{~N})$. Silicon oxide used for the synthesis of HSZ was introduced in an amount of $1-1.5 \%$ by weight. Analysis of transformation products was carried out using gas chromatography. Chromatograph "Chromatek - Kristall 5000.1" flame ionization detector and thermal conductivity detector based on the calculation program "Chromatek gasoline".

The analysis of gaseous hydrocarbons was carried out in a stainless steel column (length 3 $\mathrm{m}$, inner diameter $3 \mathrm{~mm}$ ) filled with $5 \% \mathrm{NaOH}$ in $\mathrm{Al}_{2} \mathrm{O}_{3}$ (fraction $0.25-0.50 \mathrm{~mm}$ ); liquid hydrocarbons - DB-1 quartz glass capillary column (100 $\mathrm{mx} 0.25 \mathrm{~mm} \times 0.25 \mu \mathrm{m}$ ) applied to a stationary liquid phase (SE-30 silicone oil). 
The catalytic activity of the samples obtained by converting methanol to lower olefins was studied in a catalytic unit at $400-550^{\circ} \mathrm{C}$ and $\mathrm{W}$ $=2-6 \mathrm{~g} /(\mathrm{g} * \mathrm{~h})$.

It was found that the presence of metals in the reaction mixture leads to a decrease in the crystallization rate in the HSZ > Mg-B- HSZ > Mg-Zn- HSZ > Mg-Zr- HSZ > Mg-Zn-Zr- HSZ > MgZn-Zr- HSZ > Mg-Zn-Zr-B- HSZ. For the Mg-HSZ sample, the crystal size is $6-8 \mu \mathrm{m}$, which is greater than the crystal size of the HSZ reference sample. A common problem for all synthesized samples with a high structure is the low conversion of the reaction mixture, which leads to the insufficient formation of the desired crystalline phase. The weight fraction of the obtained samples was 0.3-0.4 in the reaction mixture $m(\mathrm{MeO})+m\left(\mathrm{Al}_{2} \mathrm{O}_{3}\right)+m$ $\left(\mathrm{B}_{2} \mathrm{O}_{3}\right)+m\left(\mathrm{SiO}_{2}\right)$, which indicates the inefficient use of primary reagents. An increase in the cost-effectiveness of the crystalline phase was achieved by reducing the $\mathrm{pH}$ of the reaction mixture. This method led to the formation of a crystalline phase HSZ-1 instead of HSZ, the profitability of the HSZ-1 phase is 0.95-0.97 s of the entry-level.

A study of the acid properties of Me-HSZ using TPD ammonia showed that the introduction of metals led to an increase in the concentration of acid fields in the samples by increasing the proportion of strong acid centres and quickly removing samples in the catalytic reaction. All samples with HSZ-1 structure showed high activity and stability in catalytic conversion, which can be associated with a low proportion of strong acid sites in these materials. The best Zn-HSZ-1 sample was stable for 12 hours. The observed differences between Me-HSZ and Me-HSZ-1 may be related to differences in the acidic properties of samples.

\section{RESULTS AND DISCUSSION}

During the treatment of zeolite with magnesium, zinc, zirconium and boron compounds, acid properties changed and superacidal formation was shown (Table 1).

Table 1. Studies of acid properties of zeolites modified with magnesium, zinc, zirconium and boron.

\begin{tabular}{|c|c|c|c|c|c|}
\hline \multirow{2}{*}{ Example } & \multirow{2}{*}{$\begin{array}{c}\text { The total amount } \\
\text { of acid centres, } \\
\text { mgmol/g }\end{array}$} & \multicolumn{4}{|c|}{$\begin{array}{c}\text { The number of acidic centres (with desorption } \\
\text { activation energy, kJ / mol), mgmol/g }\end{array}$} \\
\cline { 4 - 6 } & 570 & 45 & 260 & 265 & 10 \\
\hline HSZ & 610 & 15 & 275 & 350 & 30 \\
\hline Mg-B-HSZ & 680 & 60 & 400 & 620 & 100 \\
\hline Mg-Zn-HSZ & 740 & 50 & 420 & 630 & 115 \\
\hline Mg-Zr-HSZ & 890 & 65 & 465 & 658 & 125 \\
\hline Mg-Zn-Zr-HSZ & 1240 & 72 & 720 & 735 & 138 \\
\hline Mg-Zn-Zr-B-HSZ & & & & & \\
\hline
\end{tabular}

$\mathrm{E}<95 \mathrm{~kJ} / \mathrm{mol}$ - slightly acidic centers, $95 \leq \mathrm{E}<130 \mathrm{~kJ} / \mathrm{mol}$ - moderate, $\mathrm{E} \geq 130 \mathrm{~kJ} / \mathrm{mol}$ - strong, $\mathrm{E}>180$ $\mathrm{kJ} / \mathrm{mol}$ - superacids. 
The appearance of superacidal centres allowed to reduce the reaction temperature from 330 to $270^{\circ}$ $\mathrm{C}$ while maintaining the catalytic properties of Mg-Zn-Zr-B-HSZ, as confirmed by the data of Table 2.

Table 2. Effect of temperature on the catalytic properties of HSZ and Mg-Zn-Zr-B-HSZ.

\begin{tabular}{|c|c|c|c|c|c|}
\hline \multirow{3}{*}{ Катализатор } & \multirow{3}{*}{$\mathrm{T},{ }^{\circ} \mathrm{C}$} & \multirow{3}{*}{$\begin{array}{c}\text { DME } \\
\text { conversion,\% }\end{array}$} & \multicolumn{3}{|c|}{ Selectivity, mas.\% } \\
\hline & & & \multicolumn{3}{|c|}{ Olefins } \\
\hline & & & $C_{2}$ & $C_{3}$ & $\sum \mathrm{C}_{2}-\mathrm{C}_{4}$ \\
\hline HSZ & \multirow{5}{*}{270} & 40,2 & 16,5 & 21,9 & 39,9 \\
\hline Mg-B- HSZ & & 65.6 & 17.2 & 22.3 & 41.2 \\
\hline Mg-Zn- HSZ & & 66.1 & 18.4 & 24.6 & 41.0 \\
\hline Mg-Zr- HSZ & & 67.3 & 18.6 & 20.9 & 41.5 \\
\hline Mg-Zn-Zr- HSZ & & 69.8 & 19.4 & 22.6 & 45.2 \\
\hline Mg-Zn-Zr-B- HSZ & & 79,8 & 29,8 & 30,7 & 77,4 \\
\hline HSZ & \multirow{6}{*}{320} & 65,5 & 13,6 & 19,2 & 38,3 \\
\hline Mg-B- HSZ & & 67.9 & 15.8 & 20.7 & 42.3 \\
\hline Mg-Zn- HSZ & & 72.9 & 19.2 & 23.4 & 46.8 \\
\hline Mg-Zr-HSZ & & 75.8 & 20.7 & 24.3 & 49.6 \\
\hline Mg-Zn-Zr- HSZ & & 79.2 & 23.6 & 28.8 & 56.9 \\
\hline Mg-Zn-Zr-B- HSZ & & 88.7 & 29,4 & 38,5 & 72,6 \\
\hline
\end{tabular}

Conditions: $\left(\mathrm{R}=0.1 \mathrm{MPa}, \mathrm{W}_{\mathrm{ar}}=4000 \mathrm{~h}^{-1}\right.$. Raw materials: DME (10\%) $\mathrm{N}_{2}$ (90\%). As can be seen from these data, the conversion of DME in the Mg-Zn-Zr-B-HSZ catalyst was $79.8 \%$ at $270 \mathrm{~W}_{\text {ar }}$ at $W_{a r}=4000 \mathrm{~h}^{-1}$. At the same feed space rate, the DME conversion for the HSZ catalyst is only $65.5 \%$ at $320{ }^{\circ} \mathrm{C}$. When the temperature in sample Mg-Zn-Zr-B-HSZ was lowered, the conversion of DME was slightly reduced, and the selectivity to olefins $C_{2}-C_{5}$ practically did not change. In the original unmodified sample, a sharp decrease in DME conversion to $40.2 \%$ with a decrease in temperature was observed, the olefin selectivity being decreased to 29.9 wt. \%. 
Table 3. Catalytic properties of Mg-Zn-Zr-P-HSZ and Mg-Zn-Zr-B-HSZ samples at $\mathrm{T}=270$ and $320^{\circ} \mathrm{C}$ during the conversion of DME to lower olefins.

\begin{tabular}{|c|c|c|c|c|c|}
\hline \multirow{3}{*}{ Catalyst } & \multirow{3}{*}{$\mathrm{T},{ }^{\circ} \mathrm{C}$} & \multicolumn{4}{|c|}{ Selectivity, mas.\% } \\
\hline & & \multicolumn{3}{|c|}{ Olefins } & \multirow{2}{*}{ Paraffins $C_{1}+$} \\
\hline & & $C_{2}$ & $C_{3}$ & $\sum \mathrm{C}_{2}-\mathrm{C}_{4}$ & \\
\hline Mg-Zn-Zr-P-HSZ & \multirow[b]{2}{*}{270} & 25,5 & 32,6 & 58,1 & 33,9 \\
\hline Mg-Zn-Zr-B-HSZ & & 29,8 & 30,7 & 77,4 & 22,6 \\
\hline Mg-Zn-Zr-P-HSZ & \multirow[b]{2}{*}{320} & 26,4 & 28,8 & 55,2 & 37,5 \\
\hline Mg-Zn-Zr-B-HSZ & & 29,4 & 38,5 & 72,6 & 27,4 \\
\hline
\end{tabular}

Comparison of the experimental data obtained on the samples Mg-Zn-Zr-P-HSZ and Mg-Zn-ZrB-HSZ at $270{ }^{\circ} \mathrm{C}$ and $40 \%$ of conversion of DME, showed that these systems show almost identical selectivity on the lowest olefins. As can be seen from the table, as the process temperature increased from $270{ }^{\circ} \mathrm{C}$ to $320^{\circ} \mathrm{C}$, the olefin selectivity decreased $C_{2}-C_{5}$, the number of paraffin hydrocarbons increased and reached a maximum value of $27 \mathrm{~ms}$.
However, in less than 5 hours, the Mg-Zn-Zr-BHSZ catalyst system showed high stability of operation and activity compared to Mg-Zn-Zr$\mathrm{P}-\mathrm{HSZ}$ under the same test conditions. The MgZn-Zr-B-HSZ catalyst system was sufficiently stable after several cycles of oxidative regeneration. As shown in Figure 1 , the selectivity of the catalyst system Mg-Zn-Zr-B$\mathrm{HSZ}$ to olefins $\mathrm{C}_{2}-\mathrm{C}_{5}$ was maintained at $70 \mathrm{~ms} . \%$ even after the second catalyst regeneration.

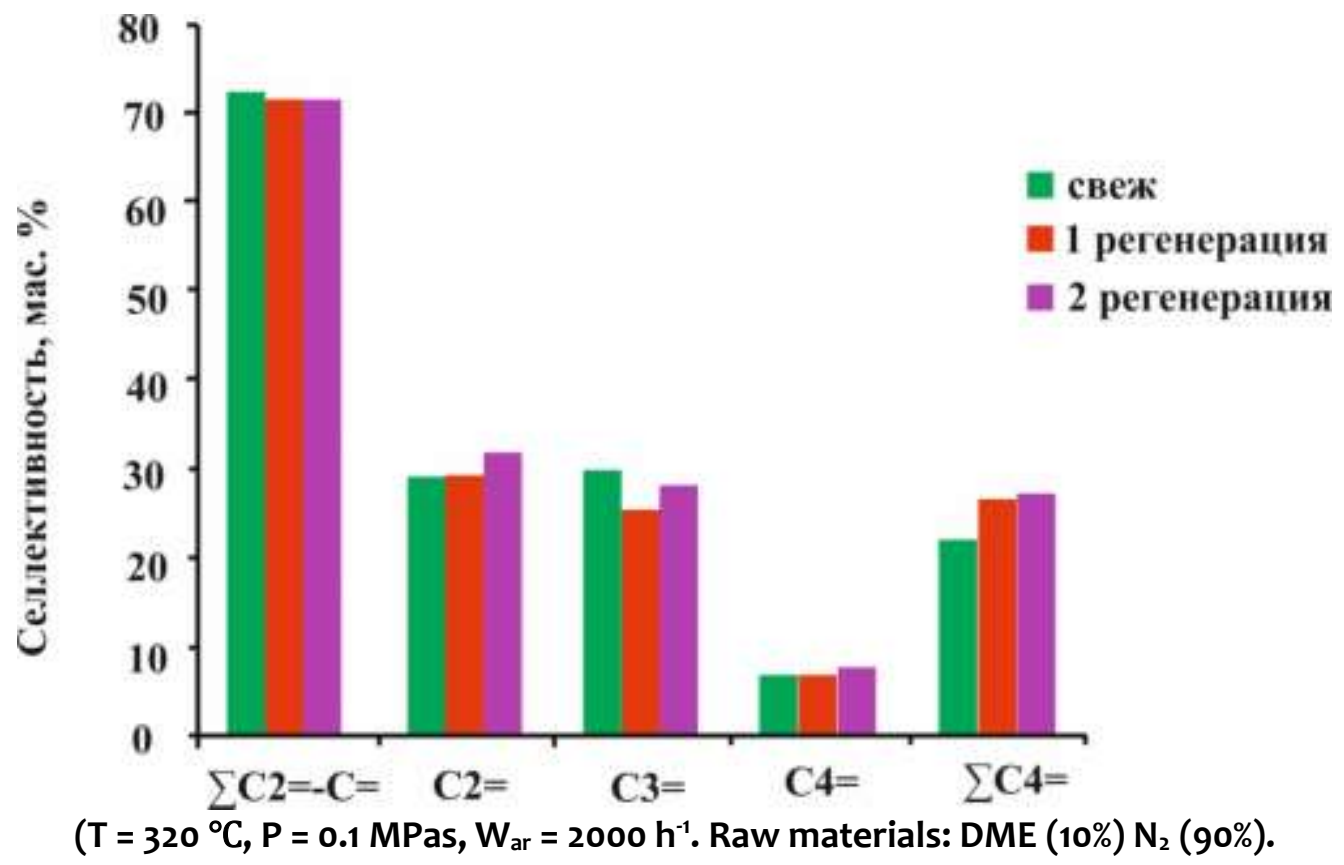


Figure 1. The dependence of DME conversion and selectivity for the target products on the regeneration rate of the oxidizing catalyst Mg-Zn-Zr-B-HSZ.

\section{CONCLUSION}

It should be noted that in samples containing zirconium, magnesium, zinc, boron and phosphorus, about 30\% of paraffin are formed, consisting mainly of isoparaffins, which are valuable high octane hydrocarbons of gasoline. Therefore, zeolite catalysts containing zirconium, magnesium, zinc, boron and phosphorus and their sulphated forms have been studied in the conversion of hydrocarbon components of gasoline to DME, where steam reforming as a diluent for producing gasoline containing small amounts of aromatic hydrocarbons has the following content: 20.8 volume $\% \mathrm{CO}, 72.3$ volume $\% \mathrm{~N}_{2}, 4.2$ volume $\% \mathrm{~N}_{2}$, 2.7 volume $\% \mathrm{CO}_{2}$ synthesis gas was used.

\section{REFERENCES}

1. Rakhmatov, S. B., \& Fayzullayev, N. I. (2020). Coke Formation of Catalyst on the Ethylene Preparation from the Oxycondensation of Methane and its Regeneration. International Journal of Advanced Science and Technology, 29(03), 7875-7884.

2. Лисицын, Н. В., Сладковский, А. А., Семикин, К. В., Куличков, А. В., \& Кузичкин, Н. В. (2013). Установка Аля получения этилена. №2013119053/04

3. Treger, Y. A., \& Rozanov, V. N. (2016). Technologies for the synthesis of ethylene and propylene from natural gas. Review Journal of Chemistry, 6(1), 83-123.

4. Chang, C. D., \& Silvestri, A. J. (1977). The conversion of methanol and other $\mathrm{O}$ compounds to hydrocarbons over zeolite catalysts. Journal of catalysis, 47(2), 249259.

5. Bjørgen, M., Joensen, F., Lillerud, K. P., Olsbye, U., \& Svelle, S. (2009). The mechanisms of ethene and propene formation from methanol over high silica H-ZSM-5 and H-beta. Catalysis Today, 142(12), 90-97.

6. Fayzullayev, N. I., Shoymardanov, T. B., Begimqulova, D. M., Hamidov, D. R., \& Rakhmatov, K. B. (2020). Kinetic Laws of Methane Carbonate Conversion Reaction. International Journal of Control and Automation, 13(4), 268-276.

7. Tursunova, N. S., \& Fayzullaev, N. I. (2020). Kinetics of the Reaction of Oxidative Dimerization of Methane. International Journal of Control and Automation, 13(2), 440-446.

8. Хамидов, А., Ахмедова, Ф., Хидирова, Ю., \& Файзуллаев, Н. (2020). Каталитический пиролиз метилхлорида. Збірник наукових праць $\Lambda$ ОГО , 79-85.

9. Fayzullaev, N. I., Akmalaev, K. A., Karjavov, A., Akbarov, H. I., \& Qobilov, E. (2020). Catalytic Synthesis of Acetone And Acetaldehyde From Acetylene In FluorideBased Catalysts. The American Journal of Interdisciplinary Innovations and Research, 2(09), 89-100.

10. Jean, L. (2005). Effect of process parameters on methanol to olefins reactions over SAPO catalysts, (Doctoral dissertation).

11. Fayzullaev, N. I., \& Sh, S. B. (2018). Catalytic aromatization of methane with 
non-mo-contained catalysts. Austrian Journal of Technical and Natural Sciences, (7-8).

12. Anvarjon o'g, S. R. Z. (2020). Mathematical Modeling Taking Into Account Features Of Different Drive States Of Pump Station Electric Drive Systems. The American Journal of Engineering and Technology, 2(09), 120-127.

13. Fayzullayev, N. I. (2019). Kinetics and mechanism of the reaction of the catalytic oxycondensation reaction of methane. Austrian Journal of Technical and Natural Sciences, (5-6).

14. Fayzullayev, N. I., \& Turobjonov, S. M. (2015). Catalytic Aromatization of Methane. International Journal of Chemical and Physical Science, 4, 27-34.

15. Roziqova, D. A., Sobirov, M. M., Nazirova, R. M., \& Hamdamova, S. (2020). Production of nitrogen-phosphoruspotassium fertilizers based on washed hot concentrate, ammonium nitrate and potassium chloride. ACADEMICIA: An International Multidisciplinary Research Journal, 10(9), 215-220.

16. Rakhmatov, S. B., \& Fayzullaev, N. I. (2019). Technology for the production of ethylene by catalytic oxycondensation of methane. European Journal of Technical and Natural Sciences, (5-6), 44-49.

17. Barger, P. (2002). Zeolites for cleaner technologies. Catalytic Science Series, 3, 239-248.

18. Fayzullaev, N. I., \& Tursunova, N. S. (2020). Termodynamic Basis of Methane Oxidation Dimerization Reaction and Process Approval. International Journal of
Advanced Science and Technology, 29(5), 6522-6531.

19. Fayzullaev, N. I., Yusupov, D., Egamberdiev, R., \& Korotoev, A. V. (2000). About mechanizm of investigation of acetone in hydration of acetilene multifunctional catalist. Uzbekskii Khimicheskii Zhurnal, (6), 40-42.

20. Cai, G., Liu, Z., Shi, R., Changqing, H., Yang, L., Sun, C., \& Chang, Y. (1995). Light alkenes from syngas via dimethyl ether. Applied Catalysis A: General, 125(1), 29-38.

21. Chen, W. H., Lin, B. J., Lee, H. M., \& Huang, M. H. (2012). One-step synthesis of dimethyl ether from the gas mixture containing $\mathrm{CO}_{2}$ with high space velocity. Applied energy, 98, 92-101.

22. Fayzullayev, N. I., \& Turobjonov, S. M. (2015). Catalytic Aromatization of Methane. International Journal of Chemical and Physical Science, 4, 27-34.

23. Air Liquide. Lurgi MTP ${ }^{\mathrm{TM}}$ - Methanol-toPropylene [Electronic resource], 2016. URL: $\quad$ https://www.engineeringairliquide.com/lurgi-mtp-methanolpropylene.

24. Bobomurodova, S. Y., Fayzullaev, N. I., \& Usmanova, K. A. (2020). Catalytic Aromatization of Oil Satellite Gases. International Journal of Advanced Science and Technology, 29(5), 3031-3039.

25. Fayzullaev, N. I., Saginaev, A. T., Shukurov, B. S., \& Holliyev, S. K. Catalytic dehydroaromatization oil associated gas. C. Өтебаев Атындағы Атырау Мұнай Және Газ Университетінің Хабаршысы, 27. 
26. Fayzullayev, N., Akmalaiuly, K., \& Karjavov, A. (2020). Catalytic synthesis of a line by acetylene hydration. News of the National Academy of Sciences of the Republic of Kazakhstan, Series chemistry and technology, 2(440), 23-30.

27. Mamadoliev, I. I., \& Fayzullaev, N. I. (2020). Optimization of the Activation Conditions of High Silicon Zeolite. International Journal of Advanced Science and Technology, 29(03), 6807-6813.

28. Fayzullaev, N. I., \& Raxmatov, S. B. (2020). Kinetics and Mechanisms of Oxycondensation Reaction in Methane Molybden-Marganets-Zirconium Catalysis. International Journal of Psychosocial Rehabilitation, 24(04).

29. Ibodullayevich, F. N., Yunusovna, B. S., \& Anvarovna, X. D. (2020). Physico-chemical and texture characteristics of Zn-Zr/VKTS catalyst. Journal of Critical Reviews, 7(7), 917-920.

30. Fayzullaev, N. I., Akmalaev, K. A., Karjavov, A., Akbarov, H. I., \& Qobilov, E. (2020). Catalytic Synthesis of Acetone And Acetaldehyde From Acetylene In FluorideBased Catalysts. The American Journal of Interdisciplinary Innovations and Research, 2(09), 89-100.

31. Fayzullaev, N. I., Jumanazarov, R. B., \& Turabjanov, S. M. (2015). Heterogeneous Catalytic Synthesis of Vinylchloride by Hydrochlorination of Acetylene. IJISETInternational Journal of Innovative Science, Engineering \& Technology, 2(9).

32. Akmalaiuly, K., Ibodullaevich, F. N., \& Rahmonovich, K. A. (2020). Joint Synthesis Of Acetone And Acetaldehyde From
Acetylene. The American Journal of Engineering and Technology, 2(09), 109-119.

33. Omanov, B. S., Fayzullayev, N. I., \& Xatamova, M. S. (2020). Catalytic synthesis of acetylene ut of vynil acetate and texture characteristics of catalysts. Asian Journal of Multidimensional Research (AJMR). Special Issue, March, 157-164.

34. Fayzullaev, N. I., Akmalaev, K. A., \& Karjavov, A. (2020). Catalytic Synthesis Of Acetone From Acetylene. The American Journal of Applied sciences, 2(09), 101-109.

35. Ugli, O. B. S., Ibodullayevich, F. N., Anorboevich, E. K., \& Sattorovna, K. M. (2020). Production of vinyl acetate from acetylene. ACADEMICIA: An International Multidisciplinary Research Journal, 10(6), 1031-1038.

36. Omanov, B. S., Fayzullayev, N. I., \& Xatamova, M. S. (2019). Vinylacetate Production out of acetylene. International Journal of Advanced Research in Science, Engineering and Technology, 6(12). 